\title{
Synthesis, Characterization and Reactivity of Nitrosyl Ruthenium Complexes with the Non-stereoidal Anti-inflammatory Diflunisal
}

\author{
Ernani Lacerda de Oliveira Neto ${ }^{1,2}$, Juliana Guerreiro Cezar ${ }^{2}$, Fabio Gorzoni Doro ${ }^{3}$, \\ Jose Roque Mota Carvalho ${ }^{2}$, Kleber Queiroz Ferreira ${ }^{2}$, \\ ${ }^{1}$ Department of Exact and Natural Sciences, State University of Southwest Bahia, Itapetinga, Brazil \\ ${ }^{2}$ Department of General and Inorganic Chemistry, Federal University of Bahia, Salvador, Brazil \\ ${ }^{3}$ Department of Chemistry, Federal University of Mining Triangle, Iturama, Brazil
}

Email address:

kqf@ufba.br (K. Q. Ferreira)

${ }^{*}$ Corresponding author

\section{To cite this article:}

Ernani Lacerda de Oliveira Neto, Juliana Guerreiro Cezar, Fabio Gorzoni Doro, Jose Roque Mota Carvalho, Kleber Queiroz Ferreira. Synthesis, Characterization and Reactivity of Nitrosyl Ruthenium Complexes with the Non-stereoidal Anti-inflammatory Diflunisal. Journal of Chemical, Environmental and Biological Engineering. Vol. 4, No. 2, 2020, pp. 39-46. doi: 10.11648/j.jcebe.20200402.12

Received: August 29, 2019; Accepted: September 2, 2019; Published: June 9, 2020

\begin{abstract}
The}_{2} \mathrm{Na}_{2}\left[\mathrm{Ru}(\mathrm{NO}) \mathrm{Cl}_{3}(\mathrm{df})\right]$ (I) and cis-[Ru(NO)(df)(cyclen)] $\mathrm{Cl}_{2}$ (II) complexes (df=diflunisal (5-(2,4-difluorophenyl)2-hydroxybenzoic acid, cyclen=1, 4, 7, 10-tetraazacyclododecane) have been synthesized and characterized by elemental analysis, electronic (UV-Vis) and vibrational (FTIR) spectroscopic techniques. FTIR data suggests different modes of coordination of the ligand diflunisal in these complexes, i.e., coordinated in the bidentate form in the compound I and in the monodentate form in the compound II, and that $\mathrm{df}$ is coordinated to ruthenium by carboxylate group in a monodentate mode for both complexes. The FTIR spectra also display $\mathrm{v}(\mathrm{NO})$ at $1880 \mathrm{~cm}^{-1}$ and $1892 \mathrm{~cm}^{-1}$ for I and II, respectively, indicating a nitrosonium (NO) character. Electronic spectra suggest that $\mathrm{df}$ is coordinated to the metal center in both complexes in catecholate form. Detailed electrochemical studies showed that complexes I and II display $\{\mathrm{RuNO}\}^{6 / 7}$ process at $-420 \mathrm{mV}$ and at $-400 \mathrm{mV}(v s . \mathrm{Ag} / \mathrm{AgCl})$ respectively, and df ligand is oxidized at $1120 \mathrm{mV}$ and at $770 \mathrm{mV}$, respectively. Controlled potential electrolysis at $-750 \mathrm{mV}$ or chemical reduction with $\mathrm{Zn}(\mathrm{Hg})$ amalgam results in $\mathrm{NO}$ release from both complexes.
\end{abstract}

Keywords: Nitrosyl Ruthenium Complex, Nitric Oxide, Diflunisal

\section{Introduction}

Nitric oxide (NO) participates in several physiological processes [1, 2], such as blood clotting, blood pressure control, in the immune system - destroying tumor cells and intracellular parasites - and in anti-inflammatory processes $[1,3,4]$. Among the various anti-inflammatory properties of $\mathrm{NO}$, it stands out the inhibition of lymphocyte proliferation and prevention and reduction of platelet adhesion and aggregation to endothelial monolayer. In addition, nitric oxide prevents the occurrence of an acute inflammatory process: it inhibits neutrophil homotypic aggregation and adhesion to the endothelium [5].

Nitrosyl metal complexes have been studied due to its ability to generate $\mathrm{NO}$ in the biological environment. It has been paid special attention to ruthenium nitrosyl complexes, which are quite robust in aqueous solutions and less toxic than similar complexes with other metals [6-9]. Ruthenium nitrosyls also display relatively high thermal stability and release nitric oxide after chemical, electrochemical or photochemical stimuli $[10,11]$. For instance, trans$\left[\mathrm{Ru}(\mathrm{NO})\left(\mathrm{NH}_{3}\right)_{4}(\mathrm{~L})\right]^{\mathrm{q}^{+}}\left(\mathrm{L}=\mathrm{P}(\mathrm{OEt})_{3}\right.$, isn, nic, L-hist, py, 4-pic, imN, imC, pz, $\mathrm{H}_{2} \mathrm{O}$ or $\mathrm{Cl}^{-}$) complexes showed $\mathrm{NO}$ release after chemical and/or electrochemical reduction. Analogous complexes with macrocyclic ligands cis- or trans$[\mathrm{Ru}(\mathrm{NO}) \mathrm{L}(\mathrm{mac})]^{\mathrm{q}^{+}} \quad(\mathrm{mac}=1,4,8,11$-tetraazacyclotetradecane (cyclam), cyclen and related ligands), besides controlled NO release, offer increasing in thermodynamic stability and display biological activity in vivo and in vitro [12]. For both 
classes of ruthenium nitrosyls, chemical properties such as electronic spectra, redox potentials and kinetics of NO release can be modulated by co-ligands coordinated to metal center.

Parallel to these important properties, there are studies involving nitrosyl complexes coordinated to species of biological interest $[13,14]$. The trans$\left[\mathrm{Ru}(\mathrm{NO})\left(\mathrm{NH}_{3}\right)_{4}(\mathrm{~L})\right]\left(\mathrm{BF}_{4}\right)_{3} \quad$ and $\quad\left[\mathrm{Ru}\left(\mathrm{NH}_{3}\right)_{5}(\mathrm{~L})\right]\left(\mathrm{BF}_{4}\right)_{3}$ $(\mathrm{L}=$ nicotinic or isonicotinic acid) complexes were studied in different experimental models, showing antinociceptive and anti-inflammatory activities [15]. The results were important in order to broaden the interest in research involving new ruthenium nitrosyl complexes with drugs that have antiinflammatory activity.

In this sense, this work involves ruthenium nitrosyl complexes with diflunisal (df) ligand - Figure 1. Diflunisal, 5-(2,4-difluorophenyl)-2-hydroxybenzoic acid, is a drug that belongs to the class of nonsteroidal anti-inflammatory drug (NSAIDs) [16]. It is more powerful and less toxic than other drugs of this class, such as aspirin and ibuprofen, and has a relatively long half-life, which reinforces its clinical application $[17,18]$.

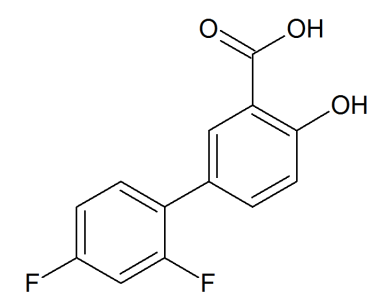

Figure 1. Structural formula of diflunisal.

The literature on coordination complexes with df is scarce [18-20]. For instance, $\left[\mathrm{Bi}(\mathrm{df})_{3}\right]$ complex showed good activity against the bacteria responsible for gastric cancer, Helicobacter pylori [19]. Copper(II) complexes with diflunisal, obtained by Fountoulaki and coworkers, showed improvement of drug interaction with human and bovine serum albumin compared to free ligand [18]. X-ray crystallographic studies involving zinc(II) complexes with o df, $\left[\mathrm{Zn}(\mathrm{df})_{2}(\mathrm{~L})_{\mathrm{x}}\right]$, ( $\mathrm{L}=$ methanol (complex $\left.\mathrm{A}\right)$, 2,2'-dipyridylamine (B), 2,2'-bipyridine (C), 1,10phenanthroline (D) or 2,2'-dipyridylketone oxime (E)) showed that $\mathrm{df}$ is coordinated to the metal center by carboxylate group in monodentate mode (complexes A and $\mathrm{E}$ ) while in complexes $\mathrm{B}$ and $\mathrm{D}$, it is coordinated in bidentate mode. It was shown that zinc diflunisal complexes were more efficient to trap DPPH (1,1-diphenyl-picrylhydrazyl), ABTS (2,2'-azinobis(3ethylbenzothiazoline-6-sulfonic acid)) and hydroxyl radicals than the free ligand and they were capable to bind to DNA and albumine [20].

However, to the best of our knowledge, there is no example of ruthenium nitrosyl complexes with diflunisal as ligand. To explore this hiatus, two strategies were devised in this work: i) coordination of $\mathrm{df}$ to a well-known [RuNO] fragment, $\left[\mathrm{Ru}(\mathrm{NO}) \mathrm{Cl}_{3}\right][21,22]$. This would allow us to gain insight on the properties of coordinated df to [RuNO] moiety and ii) design a new complex with a ligand which gives greater stability to the ruthenium nitrosyl df complex. Accordingly, the tetraazamacrocycle ligand cyclen (1,4,7,10tetraazaciclododecane) was chosen [23]. The judicious choice of cyclen were based on its properties such as greater thermodynamic stability and kinetic inertness compared to open-chain analogues [24], and on its ability to wrap-up the metal center, increase ligand field strength and to stabilize unusual oxidation states for metal ions [25-27]. Based on approaches stated above, on the ability of ruthenium nitrosyls to act as controlled NO-carriers aiming biological applications and on well documented pharmacological properties of diflunisal, this work describes the synthesis, characterization and reactivity towards $\mathrm{NO}$ release of $\mathrm{Na}_{2}\left[\mathrm{Ru}(\mathrm{NO}) \mathrm{Cl}_{3}(\mathrm{df})\right]$ and $[\mathrm{Ru}(\mathrm{NO})(\mathrm{df})($ cyclen $)] \mathrm{Cl}_{2}$ complexes.

\section{Experimental}

\subsection{Synthesis of the Complexes}

1,4,7,10-tetraazacyclododecane, ruthenium tricloronitrosyl monohydrate and tetrabutylammonium nitrite were acquired from Strem Chemicals and diflunisal from Aldrich, being used as provided. All other reagents used were of analytical grade and deionized water was used throughout the experiments. The $c i s-\left[\mathrm{RuCl}_{2}(\mathrm{dmso})_{4}\right]$ complex where dmso is dimethylsulfoxide, was prepared as already reported in the literature [28].

$\mathrm{Na}_{2}$ (diflunisal)

$500 \mathrm{mg}$ ( $2.0 \mathrm{mmol})$ of df were added in $1.5 \mathrm{~mL}$ of $\mathrm{NaOH}$ aqueous solution $\left(3 \mathrm{~mol} . \mathrm{L}^{-1}\right)$ and then added $17.5 \mathrm{~mL}$ of deionized water. The mixture was kept under stirring and heating up to $55^{\circ} \mathrm{C}$ for 10 minutes. After cooling, a white solid was separated by vacuum filtration. Yield: $93 \%(0.55 \mathrm{~g}$, $1.86 \mathrm{mmol})$.

$\mathrm{Na}_{2}\left[\mathrm{Ru}(\mathrm{NO}) \mathrm{Cl}_{3}\right.$ (diflunisal) $]$ (I)

$0.2 \mathrm{~g}(0.78 \mathrm{mmol})$ of $\mathrm{Ru}(\mathrm{NO}) \mathrm{Cl}_{3} \cdot \mathrm{H}_{2} \mathrm{O}$ was dissolved in 20 $\mathrm{mL}$ of methanol. Then, $0.46 \mathrm{~g}(1.57 \mathrm{mmol})$ of $\mathrm{Na}_{2}(\mathrm{df})$ dissolved in $12 \mathrm{~mL}$ of methanol was added to the system. The resulting mixture was kept under stirring and heating to $60^{\circ}$ $\mathrm{C}$ for 4 hours. The solid obtained after evaporation of the solvent was purified in silica chromatographic column, and eluted with acetone. After evaporated the solvent, the brown solid was washed with water at $5^{\circ} \mathrm{C}$ and dried. Yield: $44 \%$ $(0.22 \mathrm{~g}, 0.34 \mathrm{mmol})$. Elemental analysis: \% theoretical $(\%$ experimental) for $\mathrm{C}_{13} \mathrm{H}_{6} \mathrm{NO}_{4} \mathrm{~F}_{2} \mathrm{Cl}_{3} \mathrm{RuNa}_{2} .2 \mathrm{C}_{3} \mathrm{H}_{6} \mathrm{O} \quad(647.74$ g. $\left.\mathrm{mol}^{-1}\right)$ : $\mathrm{C}=35.23 \%$ (36.74\%); $\mathrm{N}=2.16 \%$ (2.08\%); $\mathrm{H}=2.80 \%$ (2.81\%); $\mathrm{Cl}=16.42 \%$ (16.18\%).

cis-[Ru(NO)(diflunisal)(cyclen) $] \mathrm{Cl}_{2}$ (II)

The $c i s-[\mathrm{Ru}(\mathrm{NO})(\mathrm{df})(\mathrm{cyclen})] \mathrm{Cl}_{2}(\mathrm{I})$ has been synthesized using methods reported for the synthesis of cis$\left[\mathrm{RuCl}_{2}\right.$ (cyclen) $] \mathrm{Cl}$, with modifications [29]. The synthesis of the complex consisted of dissolve $0.35 \mathrm{~g}(0.72 \mathrm{mmol})$ of cis$\left[\mathrm{RuCl}_{2}(\mathrm{dmso})_{4}\right]$ complex in $30 \mathrm{~mL}$ ethanol and add, drop by drop, $0.13 \mathrm{~g}(0.75 \mathrm{mmol})$ of cyclen dissolved in $10 \mathrm{~mL}$ of ethanol. The solution was kept in the reflux under argon atmosphere and agitation for 2 hours, with the color changing from light yellow to orange. After this $0.21 \mathrm{~g}(0.73 \mathrm{mmol})$ of tetrabutylammonium nitrite $\left(\mathrm{TBANO}_{2}\right)$ was added and the 
solution, which immediately had changed to reddish-brown coloring was kept the same conditions for over 2 hours. Then it was added $0.18 \mathrm{~g}(0.72 \mathrm{mmol})$ of $\mathrm{df}$, keeping the reflux conditions for 1 hour. Finally, the solution of the complex obtained has been acidulated with 3 drops of concentrated hydrochloric acid. The solid obtained was collected by vacuum filtration. Yield: 30\% (0.12 g, $0.19 \mathrm{mmol})$. Elemental analysis: \%theoretical. (\%experimental) for $\mathrm{C}_{21} \mathrm{~N}_{5} \mathrm{H}_{27} \mathrm{Cl}_{2} \mathrm{O}_{4} \mathrm{~F}_{2} \mathrm{Ru}$ (623.45g.mol $\left.{ }^{-1}\right): \mathrm{C}=40.45 \%$ (41.10\%); $\mathrm{N}=11.24 \%$ (11.78\%); $\mathrm{H}=4.37 \%$ (4.69\%).

\subsection{Physical Measurements}

Spectroscopy measures absorption in the infrared region (IV) were obtained with a FTIR spectrophotometer (FTIR) Bomem model MB-102, in the 4000 to $400 \mathrm{~cm}^{-1}$ range. The samples were prepared in the form of $\mathrm{KBr}$ disk. The absorption measurements in the ultraviolet-visible (UV-vis) were held in a spectrophotometer Hitachi model U-3501. Quartz cells were used with optical path of $1.0 \mathrm{~cm}$. Differential pulse voltammetry measurements (DPV) were carried out with potenciostato DropSens $\mu$ start200 model, coupled to a compatible microcomputer. It was used as a supporting electrolyte solution of $\mathrm{HCl} / \mathrm{KCl}\left(0.1 \mathrm{~mol} . \mathrm{L}^{-1} ; \mathrm{pH} 1\right)$ or in a mixture of acetonitrile with acetate buffer ( $\mathrm{pH} 4.4 ; 0.1$ mol. $\left.\mathrm{L}^{-1}\right)$. The system consisted of an electrolytic cell with Platinum wire as auxiliary electrode, glassy carbon as working electrode and $\mathrm{Ag} / \mathrm{AgCl}\left(\mathrm{KCl} 3 \mathrm{~mol} . \mathrm{L}^{-1}\right)$ as reference electrode.

\section{Results and Discussion}

\subsection{Synthesis of $\mathrm{Na}_{2}\left[\mathrm{Ru}(\mathrm{NO}) \mathrm{Cl}_{3}(\mathrm{df})\right]$ (I)}

For the complex I, the white salt $\mathrm{Na}_{2}(\mathrm{df})$ was obtained by previously dissolving the df in aqueous solution of $\mathrm{NaOH}$. In this condition, the $\mathrm{df}$ on deprotonated form is favored. In the synthesis of the complex, the precursor $\mathrm{Ru}(\mathrm{NO}) \mathrm{Cl}_{3} \cdot \mathrm{H}_{2} \mathrm{O}$ was dissolved in methanol forming a purple solution. After the addition of $\mathrm{Na}_{2}(\mathrm{df})$, it was observed a change of colour to a dark brown. It is proposed that occurred the coordination of $\mathrm{df}^{2-}$ to the coordinative unsaturated complex (equation 1). Front of the $\mathrm{Ru}(\mathrm{II})$, the df acts as a $\sigma$-donor ligand through the deprotonated oxygen atoms, one of the carboxylate group and another of hydroxyl group. The formation of these bonds releases heat that helps to make the formation of complex spontaneous.

$$
\mathrm{Ru}(\mathrm{NO}) \mathrm{Cl}_{3} \cdot \mathrm{H}_{2} \mathrm{O}+\mathrm{Na}_{2} \mathrm{df} \rightleftarrows \mathrm{Na}_{2}\left[\mathrm{Ru}(\mathrm{NO}) \mathrm{Cl}_{3}(\mathrm{df})\right]
$$

\subsection{Synthesis of cis-[Ru(NO)(df)(cyclen) $] \mathrm{Cl}_{2}(\mathrm{II})$}

In the obtaining of the compound cis$[\mathrm{Ru}(\mathrm{NO})(\mathrm{df})($ cyclen $)] \mathrm{Cl}_{2}$ from the cis- $\left[\mathrm{RuCl}_{2}\left(\mathrm{dmso}_{4}\right]\right.$, the precursor was added in ethanol and it was formed an emulsion of yellow color. After the addition of the cyclen, was observed that the solution acquired a more intense coloration, indicating the coordination of cyclen to $\mathrm{Ru}(\mathrm{II})$.

$$
\text { cis- }\left[\mathrm{Ru}^{\mathrm{II}} \mathrm{Cl}_{2}(\mathrm{dmso})_{4}\right]+\text { cyclen } \longleftrightarrow \text { cis- }\left[\mathrm{Ru}^{\mathrm{II}} \mathrm{L}_{2}(\text { cyclen })\right]^{\mathrm{n}+}
$$

Then, $\mathrm{TBANO}_{2}$ was added to the solution, inducing the release of another ligand, which can be $\mathrm{Cl}^{-}$or DMSO (equation 3). This replacement is justified by the fact that the nitrite act as $\sigma$-donor and $\pi$-acceptor front of $\mathrm{Ru}(\mathrm{II})$, while $\mathrm{Cl}^{-}$

and dmso act solely as $\sigma$-donors. In this way, the shared electron density, and therefore the strength of the bond, will be larger in $\mathrm{Ru}(\mathrm{II})-\mathrm{NO}_{2}{ }^{-}$than in $\mathrm{Ru}(\mathrm{II})-\mathrm{Cl}$ or $\mathrm{Ru}(\mathrm{II})$-dmso.

$$
\text { cis-[Ru } \left.\left.{ }^{\mathrm{II}} \mathrm{L}_{2}(\text { cyclen })\right]^{\mathrm{n}+}+\mathrm{TBANO}_{2} \rightleftarrows \text { cis-[Ru }\left(\mathrm{NO}_{2}\right) \mathrm{L}(\text { cyclen })\right]^{\mathrm{n}+}
$$

The coordination of diflunisal to $\mathrm{Ru}(\mathrm{II})$ can be represented by the equation 4 :

$$
\text { cis-[Ru } \left.{ }^{\mathrm{II}}\left(\mathrm{NO}_{2}\right) \mathrm{L}(\text { cyclen }]^{\mathrm{n}+}+\mathrm{df} \rightleftarrows \text { cis-[Ru }{ }^{\mathrm{II}}\left(\mathrm{NO}_{2}\right)(\mathrm{df})(\text { cyclen })\right]^{\mathrm{n}+}
$$

Finally, the solution was acidulated and precipitated a hygroscopic brown solid (see equation 5).

$$
c i s-\left[\mathrm{Ru}^{\mathrm{II}}\left(\mathrm{NO}_{2}\right)(\mathrm{df})(\mathrm{cyclen})\right]^{\mathrm{n}+}+\mathrm{HCl}(\mathrm{aq}) \rightleftarrows c i s-\left[\mathrm{Ru}^{\mathrm{II}}(\mathrm{NO})(\mathrm{df})(\mathrm{cycnel})\right] \mathrm{Cl}_{2}(\mathrm{~s})
$$

The conversion of nitrite ion $\left(\mathrm{NO}_{2}^{-}\right)$in coordinated nitric oxide (NO) is representated by equations $6-8$ [31]. Through an acid-base Bronsted reaction, in which the $\mathrm{NO}_{2}^{-}$ion reacts with $\mathrm{H}_{2} \mathrm{O}$, the intermediate $\left[\mathrm{MX}_{5} \mathrm{NO}_{2} \mathrm{H}\right]^{(\mathrm{n}-1)}$ is formed (eq. 6).
The second step is the nucleophilic elimination reaction (eq. 7). The latter illustrates an equilibrium of ion formation, forming the final product with coordinate NO (eq. 8).

$$
\begin{aligned}
{\left[\mathrm{MX}_{5} \mathrm{NO}_{2}\right]^{(\mathrm{n}-2)}+\mathrm{H}_{2} \mathrm{O} } & \rightleftarrows\left[\mathrm{MX}_{5} \mathrm{NO}_{2} \mathrm{H}\right]^{(\mathrm{n}-1)}+\mathrm{OH}^{-} \\
{\left[\mathrm{MX}_{5} \mathrm{NO}_{2} \mathrm{H}\right]^{(\mathrm{n}-1)} } & \rightleftarrows\left[\mathrm{MX}_{5} \mathrm{NO}\right]^{\mathrm{n}} \cdot \mathrm{OH}^{-} \\
{\left[\mathrm{MX}_{5} \mathrm{NO}^{\mathrm{n}} \cdot \mathrm{OH}^{-}\right.} & \rightleftarrows\left[\mathrm{MX}_{5} \mathrm{NO}\right]^{\mathrm{n}}+\mathrm{OH}^{-}
\end{aligned}
$$




\subsection{Spectroscopic and Redox Properties}

In order to gain structural information on $\mathrm{Na}_{2}\left[\mathrm{Ru}(\mathrm{NO}) \mathrm{Cl}_{3}(\mathrm{df})\right]$ and $c i s-[\mathrm{Ru}(\mathrm{NO})(\mathrm{df})($ cyclen $)] \mathrm{Cl}_{2}$, these complexes were characterized by FTIR. Main vibrational spectral data collected are in Table 1 .

Table 1. Vibrational spectral data (in $\left.\mathrm{cm}^{-1}\right)$ of $d f, \mathrm{Na}_{2}\left[\mathrm{Ru}(\mathrm{NO}) \mathrm{Cl}_{3}(\mathrm{df})\right]$ (I) and cis-[Ru(NO)(df)(cyclen)]Cl 2 (II).

\begin{tabular}{llll}
\hline Assignment & Df & I & II \\
\hline $\mathrm{v}(\mathrm{OH})$ & 3427,3124 & 3448,3230 & 3400,3120 \\
$\mathrm{v}(\mathrm{NO})$ & - & 1880 & 1892 \\
$\mathrm{v}(\mathrm{C}=\mathrm{O})$ & 1690 & 1614 & 1623 \\
$\mathrm{v}_{\mathrm{as}}(\mathrm{COO})$ & 1620 & 1595 & 1488 \\
$\mathrm{v}_{\mathrm{s}}(\mathrm{COO})$ & 1516 & 1381 & 1296 \\
$\Delta \mathrm{v}(\mathrm{COO})$ & 104 & 214 & 192 \\
$\mathrm{v}_{(\mathrm{C}-\mathrm{F})}$ & 1269 & 1246 & 1072 \\
\hline
\end{tabular}

The asymmetric and symmetric stretching bands of carbonyl groups $\left(\mathrm{v}_{\mathrm{as}} \mathrm{COO}\right.$ and $\left.\mathrm{v}_{\mathrm{s}} \mathrm{COO}\right)$ were readily assigned in df, $\mathrm{Na}_{2}\left[\mathrm{Ru}(\mathrm{NO}) \mathrm{Cl}_{3}(\mathrm{df})\right]$ and cis-[Ru(NO)(df)(cyclen) $] \mathrm{Cl}_{2}$ vibrational spectra. As Table 1 shows, there is a shift of $v_{\mathrm{as}}(\mathrm{COO})$ and $v_{\mathrm{s}}(\mathrm{COO})$ to lower energy region in the complexes compared to df free ligand due to carboxyl group deprotonation and coordination to [RuNO] core. The region in FTIR spectra of $v_{\mathrm{as}}(\mathrm{COO})$ and $\mathrm{v}_{\mathrm{s}}(\mathrm{COO})$ observed for our nitrosyl ruthenium complexes is close to those observed for other metal complexes with df $[18,19]$. The $\Delta v(\mathrm{COO})$, $\Delta\left(v_{\text {as }}(\mathrm{COO}){ }_{2} v_{\mathrm{s}}(\mathrm{COO})\right)$, has been largely used to analyze the coordination mode of the carboxylate group. In both complexes, the $\Delta \mathrm{v}(\mathrm{COO})$ is greater than 190 and suggests a monodentate binding mode of carboxylate group to $\mathrm{Ru}[32$, $33,34]$. Since the synthetic route for $\mathrm{Na}_{2}\left[\mathrm{Ru}(\mathrm{NO}) \mathrm{Cl}_{3}(\mathrm{df})\right]$ involves the fully deprotonated df ligand $\left(\mathrm{Na}_{2} \mathrm{df}\right)$, coordination to $\mathrm{Ru}$ is likely to occurs through one oxygen atom of the carboxylate group and the oxygen of the deprotonated phenolate group.

The FTIR spectra of $\mathrm{Na}_{2}\left[\mathrm{Ru}(\mathrm{NO}) \mathrm{Cl}_{3}(\mathrm{df})\right]$ and cis$[\mathrm{Ru}(\mathrm{NO})(\mathrm{df})($ cyclen $)] \mathrm{Cl}_{2}$ display one strong band at 1880 and $1892 \mathrm{~cm}^{-1}$, respectively, which are absent in starting compounds and were assigned to the stretching of the coordinated NO. The spectral range of these bands is consistent with the nitrosonium $\left(\mathrm{NO}^{+}\right)$character of nitrosyl ligand $[29,35,36]$.

Table 2. Electronic spectroscopic data for $d f$, $\left[R u(N O) C_{3}(d f)\right]^{2-}$ (I) and cis$[R u(N O)(d f)(\text { cyclen })]^{2+}(I I)$.

\begin{tabular}{llll}
\hline & $\boldsymbol{\lambda}(\mathbf{n m})$ & $\log \boldsymbol{\varepsilon}$ & Assignment \\
\hline \multirow{4}{*}{ df } & 207 & 4.4 & IL $\left(\pi \rightarrow \pi^{*}\right)$ \\
& 225 & 4.2 & IL $\left(\pi \rightarrow \pi^{*}\right)$ \\
& 254 & 3.9 & IL $\left(\pi \rightarrow \pi^{*}\right)$ \\
I & 310 & 3.3 & IL $\left(\pi \rightarrow \pi^{*}\right)$ \\
& 326 & 3.5 & IL $\left(\pi \rightarrow \pi^{*}\right)$ \\
II & 381 & 3.2 & MLCT \\
& 260 & 3.3 & IL $\left(\pi \rightarrow \pi^{*}\right)$ \\
& 340 & 3.0 & MLCT \\
\hline
\end{tabular}

The electronic spectroscopic data for df, $\left[\mathrm{Ru}(\mathrm{NO}) \mathrm{Cl}_{3}(\mathrm{df})\right]^{2-}$ and $c i s-[\mathrm{Ru}(\mathrm{NO})(\mathrm{df})(\text { cyclen })]^{2+}$ are presented in table 2 . For the $\mathrm{df}$, the bands observed in the ultraviolet region were assigned to transitions between characteristic ligand orbitals of type $\pi \rightarrow \pi^{*}[18]$. The $\left[\mathrm{Ru}(\mathrm{NO}) \mathrm{Cl}_{3}(\mathrm{df})\right]^{2-}$ and cis$[\mathrm{Ru}(\mathrm{NO})(\mathrm{df})(\mathrm{cyclen})]^{2+}$ complexes showed $\pi \rightarrow \pi^{*}$ transition of coordinated df ligand, and bands at $381 \mathrm{~nm}$ for $\left[\mathrm{Ru}(\mathrm{NO}) \mathrm{Cl}_{3}(\mathrm{df})\right]^{2-}$ and $340 \mathrm{~nm}$ for cis$[\mathrm{Ru}(\mathrm{NO})(\mathrm{df})(\text { cyclen })]^{2+}$, which were assigned to metal to ligand charge transition (MLCT) $d \pi(\mathrm{Ru}) \rightarrow \pi^{*}\left(\mathrm{NO}^{+}\right)$based on similar complexes [10]. For complex II, one broad band in $460 \mathrm{~nm}$ is assigned to MLCT $\mathrm{d} \pi(\mathrm{Ru}) \rightarrow \pi^{*}(\mathrm{df})$ with contribution of $\mathrm{d} \pi(\mathrm{Ru}) \rightarrow \pi^{*}\left(\mathrm{NO}^{+}\right)$.

Based on analogous ligands, the df ligand can coordinate to the metal center in the form of catecholate or in the oxidized forms semiquinone or quinone [32, 36-38]. Complexes containing the $\mathrm{Ru}^{\mathrm{II}}$-(quinone) fragment show an intense band in the visible region associated with MLCT $\mathrm{d} \pi(\mathrm{Ru}) \rightarrow \pi^{*}$ (quinone) [39, 40]. The complexes $\left[\mathrm{Ru}^{\mathrm{II}}\left(\mathrm{NH}_{3}\right)_{4}(\mathrm{Q}-\mathrm{R})\right]$ (Q is quinine and $\mathrm{R}$ is $\mathrm{H}, \mathrm{OCH}_{3}$ or $\mathrm{CO}_{2}$ ) show band in 515,510 and $519 \mathrm{~nm}$, respectively, with molar absorptivity approximately $7,9 \times 10^{3} \mathrm{M}^{-1} \cdot \mathrm{cm}^{-1}$. However, the $\left[\mathrm{Ru}^{\mathrm{II}}\left(\mathrm{NH}_{3}\right)_{4}(\mathrm{Cat}-\mathrm{R})\right]$ complexes (Cat is cathecolate) did not show any band in the visible region with high intensity [40]. The same was observed in the electronic spectra of $\left[\mathrm{Ru}(\mathrm{NO}) \mathrm{Cl}_{3}(\mathrm{df})\right]^{2-}$ and $c i s-[\mathrm{Ru}(\mathrm{NO})(\mathrm{df})(\text { cyclen })]^{2+}$ that did not show intense bands in this region. This fact supports the proposal that $\mathrm{df}$ is coordinated to the metal center in the catecholate form.

It has been shown that reduction of ruthenium nitrosyl complexes is a key step to control NO release $[6,7,9,10]$. The $\left\{\mathrm{RuNO}^{6 / 7}\right.$ (formally $\mathrm{NO}^{+} / \mathrm{NO}^{0}$ ) reduction potentials span over a broad range (from 537 to $-340 \mathrm{mV} v \mathrm{NHE}$ ) (for trans $-\left[\mathrm{Ru}(\mathrm{NO})(\mathrm{bpy})_{2}\left(\mathrm{SO}_{3}\right)\right]^{+}, \mathrm{E}_{(\mathrm{NO}+\mathrm{NO})}=-340 \mathrm{mV}$; for trans$\left[\mathrm{Ru}(\mathrm{NO})\left(\mathrm{NH}_{3}\right)_{4}(\mathrm{imC})\right]^{3+}, \mathrm{E}_{(\mathrm{NO}+\mathrm{NO})}=-298 \mathrm{mV}$; and for cis$\left.\left[\mathrm{Ru}(\mathrm{NO})(\mathrm{bpy})_{2}(\mathrm{isn})\right]^{3+}, \mathrm{E}_{(\mathrm{NO}+\mathrm{NO})}=537 \mathrm{mV}\right)$ and most of them are accessible to important biological reductors $[6,29,41-$ 44]. Thus $\left[\mathrm{Ru}(\mathrm{NO}) \mathrm{Cl}_{3}(\mathrm{df})\right]^{2-}$ and $c i s-[\mathrm{Ru}(\mathrm{NO})(\mathrm{df})(\text { cyclen })]^{2+}$ complexes were studied by electrochemical techniques.

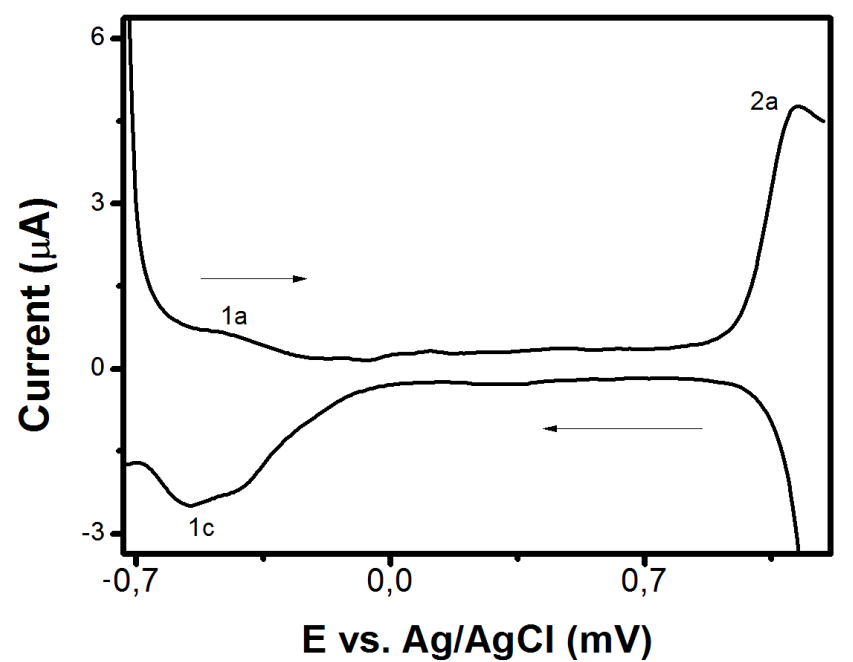

Figure 2. Differential pulse voltammogram of $\left[\mathrm{Ru}(\mathrm{NO}) \mathrm{Cl}_{3}(\mathrm{df})\right]^{2-}\left(9.30 \times 10^{-4}\right.$ mol. $\left.L^{-1}\right)$ in acetonitrile, using acetate buffer solution $\mathrm{pH} 4.4\left(0.1 \mathrm{molL}^{-1}\right)$ as supporting electrolyte. $v=50 \mathrm{mV} \cdot \mathrm{s}^{-1}$. 


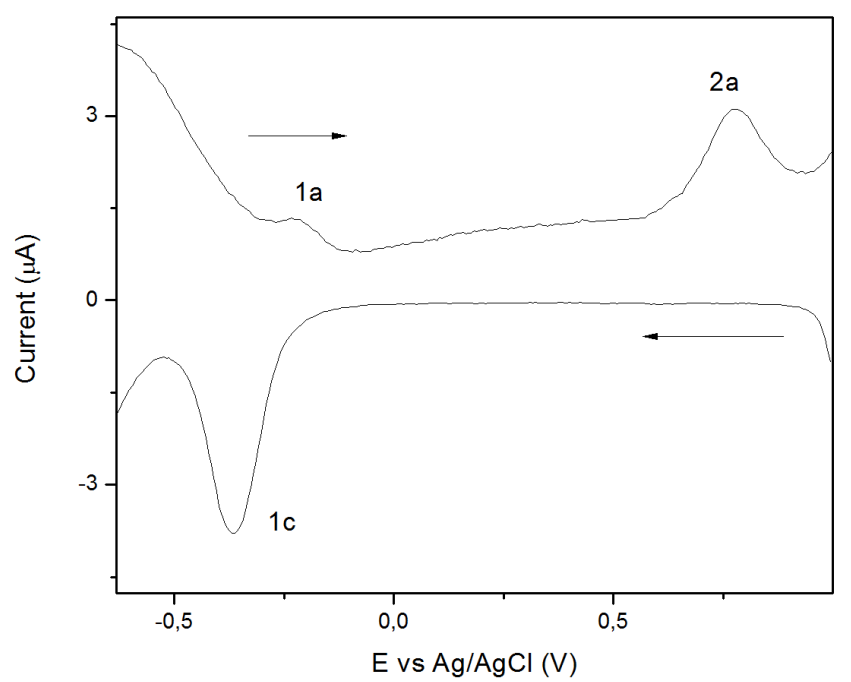

Figure 3. Differential pulse voltammogram of cis-[Ru(NO) $(\mathrm{df})(\mathrm{cyclen})]^{2+}$ $\left(2.40 \times 10^{-3}\right.$ mol. $\left.L^{-1}\right)$ in $\mathrm{HCl} / \mathrm{KCl} \mathrm{pH} 1\left(0.1 \mathrm{~mol} . \mathrm{L}^{-1}\right)$ as supporting electrolyte. $v=50 \mathrm{mV} \cdot \mathrm{s}^{-1}$.

The differential pulse voltommograms (DPV) obtained for $\left[\mathrm{Ru}(\mathrm{NO}) \mathrm{Cl}_{3}(\mathrm{df})\right]^{2-}$ and $c i s-[\mathrm{Ru}(\mathrm{NO})(\mathrm{df})(\text { cyclen })]^{2+}$ complexes are shown in figures 2 and 3 .

In general, the electrochemical processes in the range of 1000 and $-750 \mathrm{mV}$ (vs $\mathrm{Ag} / \mathrm{AgCl}$ ) in both voltammograms appear similar. The anodic scans show two peaks (1a and 2a)

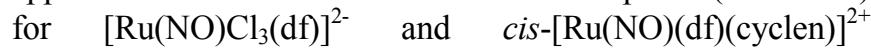
complexes at $-450 \mathrm{mV}\left(\mathrm{E}_{\mathrm{ap} 1}\right)$ and $1120 \mathrm{mV}\left(\mathrm{E}_{\mathrm{ap} 2}\right)$ and -220 $\mathrm{mV}\left(\mathrm{E}_{\mathrm{ap} 1}\right)$ and $770 \mathrm{mV}\left(\mathrm{E}_{\mathrm{ap} 2}\right)$, respectively. The cathodic scan shows one signal (1c) for the complex $\left[\mathrm{Ru}(\mathrm{NO}) \mathrm{Cl}_{3}(\mathrm{df})\right]^{2-}$ at $420 \mathrm{mV}$ which is close to that of cis-[Ru(NO)(df)(cyclen) $]^{2+}(-$ $400 \mathrm{mV})$. The values of peak potentials are collected in table 3 .

Table 3. Electrochemical data ( $\mathrm{mV} v \mathrm{sg} / \mathrm{AgCl})$ for $\mathrm{df}$, $\left[\mathrm{Ru}(\mathrm{NO}) \mathrm{Cl}_{3}(\mathrm{df})\right]^{2-}$ and cis- $[R u(N O)(d f)(\text { cyclen })]^{2+}$ and the complexes.

\begin{tabular}{lllll}
\hline Compound & $\mathbf{E}_{\text {ap1 }}$ & $\mathbf{E}_{\text {ap2 }}$ & $\mathbf{E}_{\text {cp1 }}$ & $\mathbf{E}_{\text {cp2 }}$ \\
\hline $\mathrm{Df}$ & - & 920 & - & 950 \\
{$\left[\mathrm{Ru}(\mathrm{NO}) \mathrm{Cl}_{3}(\mathrm{df})\right]^{2-}$} & -450 & 1120 & -420 & - \\
${\text { cis-[}\left[\mathrm{Ru}(\mathrm{NO})(\mathrm{df}) \text { cyclen }^{2+}\right.}^{2-}$ & -360 & 770 & -400 & - \\
\hline
\end{tabular}

The oxidation of hydroxyl group in hydroxybenzene compounds can be a process of one or two electrons forming hydroquinone and quinone, respectively. Based on data for compounds analogous to df $[13,36,38]$, the oxidation process $\left(\mathrm{E}_{\mathrm{pa} 2}\right)$ involves two electrons and it is related to the formation of quinone form of $\mathrm{df}$ free ligand [38]. Accordingly, cathodic peak $\left(\mathrm{E}_{\mathrm{pc} 2}\right)$ is related to the reduction of quinone.

Oxidation potential of coordinated df ligand $\left(\mathrm{E}_{\mathrm{ap} 2}\right)$ in the voltammograms obtained for $\left[\mathrm{Ru}(\mathrm{NO}) \mathrm{Cl}_{3}(\mathrm{df})\right]^{2-}$ and cis$[\mathrm{Ru}(\mathrm{NO})(\mathrm{df})(\text { cyclen })]^{2+}$ displays opposite behavior regarding the value determined for free df. While for the former complex, $\mathrm{E}_{\mathrm{pa} 2}$ appears shifted $200 \mathrm{mV}$ to more positive potentials, for the later compound it is shifted $150 \mathrm{mV}$ to less positive potentials. This amendment is consistent with vibrational spectroscopy data, which suggests a different mode of coordination of the diflunisal ligand in these complexes, i.e., coordinated in the bidentate mode in
$\mathrm{Na}_{2}\left[\mathrm{Ru}(\mathrm{NO}) \mathrm{Cl}_{3}(\mathrm{df})\right]$ and in monodentate in cis$[\mathrm{Ru}(\mathrm{NO})(\mathrm{df})(\mathrm{cyclen})] \mathrm{Cl}_{2}$. These results indicate that the coordination of the diflunisal ligand in bidentate mode to $\mathrm{Ru}$ (II) leads to a less thermodynamically favorable oxidation of the ligand. This is a consequence of the back-donation of electron density from $\mathrm{Ru} \mathrm{d}_{\pi}$ orbitals to the orbital $\pi^{*}$ of the ligand which lowers the energy of orbital from which electron will be removed. For both complexes, no cathodic peaks characteristic of the quinone reduction process formed after the oxidation of diflunisal were observed in positive potentials The absence of these signals are in agreement with the voltammogram of the free ligand, in which the area of the cathodic peak is much smaller than that of the anodic one. This is possibly due to existence of a coupled chemical reaction, which occurs after quinone formation and, consequently, the short life of this specie. [17, 38]

The cathodic peaks in negative potentials appears in the range associated with $\{\mathrm{RuNO}\}^{6 / 7}$ (formally $\mathrm{NO}^{+} / \mathrm{NO}^{0}$ ) redox process observed for nitrosyl ruthenium complexes [29, 40]. Thus, the cathodic peaks $\left(\mathrm{E}_{\mathrm{cp} 1}\right)$ can be assigned to the $\{\mathrm{RuNO}\}^{6 / 7}$ reducing process for diflunisal ruthenium nitrosyl complexes (Eq. 9) [35, 45, 46]. The lower current intensity observed for the correspondent anodic peaks $\left(\mathrm{E}_{\mathrm{ap} 1}\right)$ can be attributed to a coupled aquation reaction which follows the reduction of $\mathrm{NO}^{+}$(Eq. 10) [29, 45].

$$
\begin{gathered}
{\left[\mathrm{Ru}^{\mathrm{II}}\left(\mathrm{NO}^{+}\right)(\mathrm{df})(\mathrm{L})\right]^{\mathrm{q}}+\mathrm{e}^{-} \rightleftarrows\left[\mathrm{Ru}^{\mathrm{II}}\left(\mathrm{NO}^{0}\right)(\mathrm{df})(\mathrm{L})\right]^{\mathrm{q}-1}} \\
{\left[\mathrm{Ru}^{\mathrm{II}}\left(\mathrm{NO}^{0}\right)(\mathrm{df})(\mathrm{L})\right]^{\mathrm{q}-1}+\mathrm{H}_{2} \mathrm{O} \rightleftarrows\left[\mathrm{Ru}^{\mathrm{II}}\left(\mathrm{OH}_{2}\right)(\mathrm{df})(\mathrm{L})\right]^{\mathrm{q}-1}+\mathrm{NO}^{0}(10)} \\
{\left[\mathrm{Ru}^{\mathrm{II}}\left(\mathrm{OH}_{2}\right)(\mathrm{df})(\mathrm{L})\right]^{\mathrm{q}-1}-\mathrm{e}^{-} \rightleftarrows\left[\mathrm{Ru}^{\mathrm{III}}\left(\mathrm{OH}_{2}\right)(\mathrm{df})(\mathrm{L})\right]^{\mathrm{q}}}
\end{gathered}
$$

In order to support the assignment of $E_{\mathrm{cp} 1}$ processes proposed above as well as NO release, $[\mathrm{Ru}(\mathrm{NO})(\mathrm{df}) \mathrm{L}]^{\mathrm{q}}$ complexes were submitted to electrolysis at $-750 \mathrm{mV}$ and electrochemical changes were followed by DPV. Results obtained for $c i s-[\mathrm{Ru}(\mathrm{NO})(\mathrm{df})(\text { cyclen })]^{2+}$ complex are showed in Figure 4.

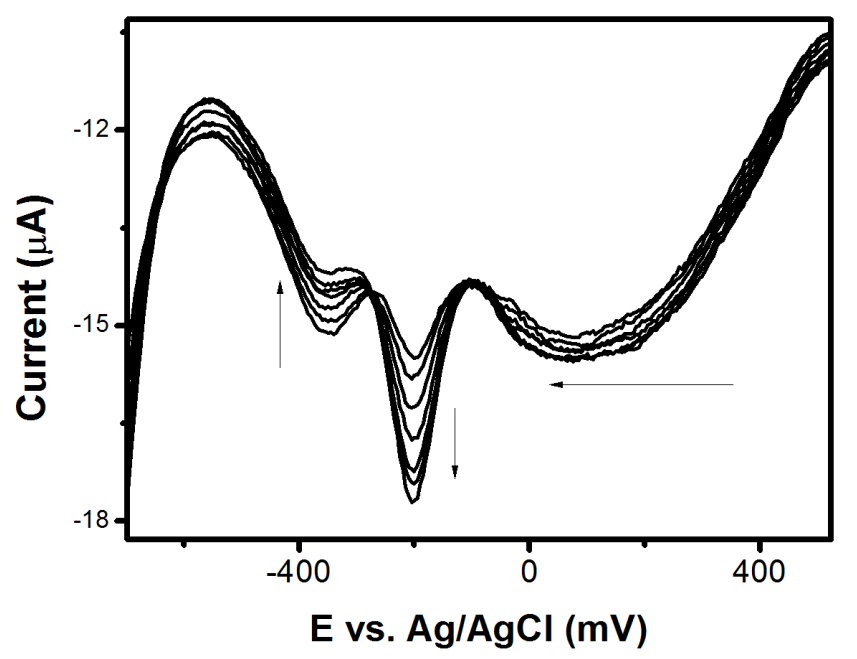

Figure 4. Changes in DPV during electrolysis of cis- $[R u(N O)(d f)(c y c l e n)]^{2+}$ at $-750 \mathrm{mV}$ at $30 \mathrm{~s}$ time intervals. $\left(C=1.52 \times 10^{-3} \mathrm{~mol} . \mathrm{L}^{-1}\right)$ in $\mathrm{HCl} / \mathrm{KCl}(\mu=0.1$ mol. $L^{-1}$; $p H$ 1) as supporting electrolyte. Scan range 500 to $-750 \mathrm{mV}$ vs. $\mathrm{Ag} / \mathrm{AgCl} . \mathrm{v}=50 \mathrm{mV} \cdot \mathrm{s}^{-1}$. 
As figure 4 shows, there is a decrease in the peak current of $\mathrm{E}_{\mathrm{cp} 1}$ during electrolysis of $c i s-[\mathrm{Ru}(\mathrm{NO})(\mathrm{df})(\text { cyclen })]^{2+}$. As it can also be seen, a new peak appears at around $-200 \mathrm{mV}$. The intensity of its peak current increases as electrolysis proceeds. These results are consistent with NO release after electrochemical reduction with consequent formation of $\mathrm{Ru}(\mathrm{II})$ aquo complex. Accordingly, this new peak can be assigned to the $\mathrm{Ru}^{\mathrm{III}} / \mathrm{Ru}^{\mathrm{II}}$ reduction in aquo complex [10]. For $\left[\mathrm{Ru}(\mathrm{NO}) \mathrm{Cl}_{3}(\mathrm{df})\right]^{2-}$, there is also a decrease in the peak current of $\mathrm{E}_{\mathrm{cp}} 1$ during the electrolysis, which is consistent with the release of nitric oxide. However, it is not observed the appearance of a new peak.

After reduction of the complexes with zinc amalgam $(\mathrm{Zn}(\mathrm{Hg})) \quad\left(\mathrm{E}_{\text {red }}^{\mathrm{o}}=-591 \mathrm{mV}\right.$ vs $\left.\mathrm{Ag} / \mathrm{AgCl}\right)$, it is checked a subsequent decrease in intensity of cathodic wave 1c in DPV for both complexes, as it can be seen in Figure 5 for the complex II. These are consistent with the release of nitric oxide from the coordination sphere of the complex (equation 7) after chemical reduction $[29,45]$. In addition, for the complex II, it is verified appearance of sign in $-190 \mathrm{mV}$, with concomitant increase in signal strength, assigned to the $\mathrm{Ru}^{\mathrm{III}} / \mathrm{Ru}^{\mathrm{II}}$ reduction, after NO release (Eq. 10) [10].

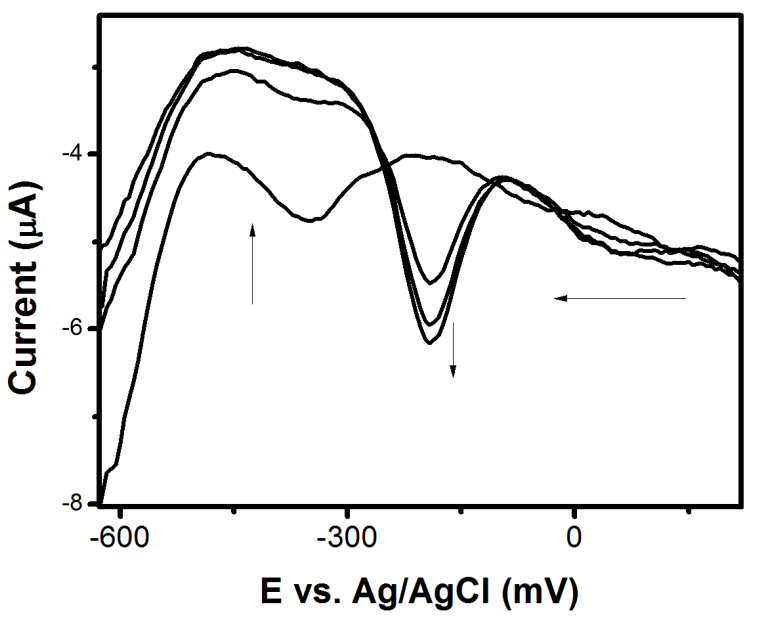

Figure 5. $D P V$ for cis- $[R u(N O)(d f)(\text { cyclen })]^{2+}$ complex $\left(C=2.40 \times 10^{-3}\right.$ mol. $\left.L^{-1}\right)$ in $\mathrm{HCl} / \mathrm{KCl}\left(\mu=0.1 \mathrm{~mol} . \mathrm{L}^{-1} ; \mathrm{pH} \mathrm{1}\right)$ as supporting electrolyte, after chemical reduction with $\mathrm{Zn}(\mathrm{Hg})$ at various time intervals. Sweeps the range $800 \mathrm{mV}$ to $-800 \mathrm{mVvs} . \mathrm{Ag} / \mathrm{AgCl}, \mathrm{v}=50 \mathrm{mV} . \mathrm{s}^{-1}$, at $15 \mathrm{~min}$ time intervals.

To confirm the release of NO in the complexes after reduction with $\mathrm{Zn}$ amalgam, vibrational spectra were acquired before and after reduction, as can be verified in Figure 6.

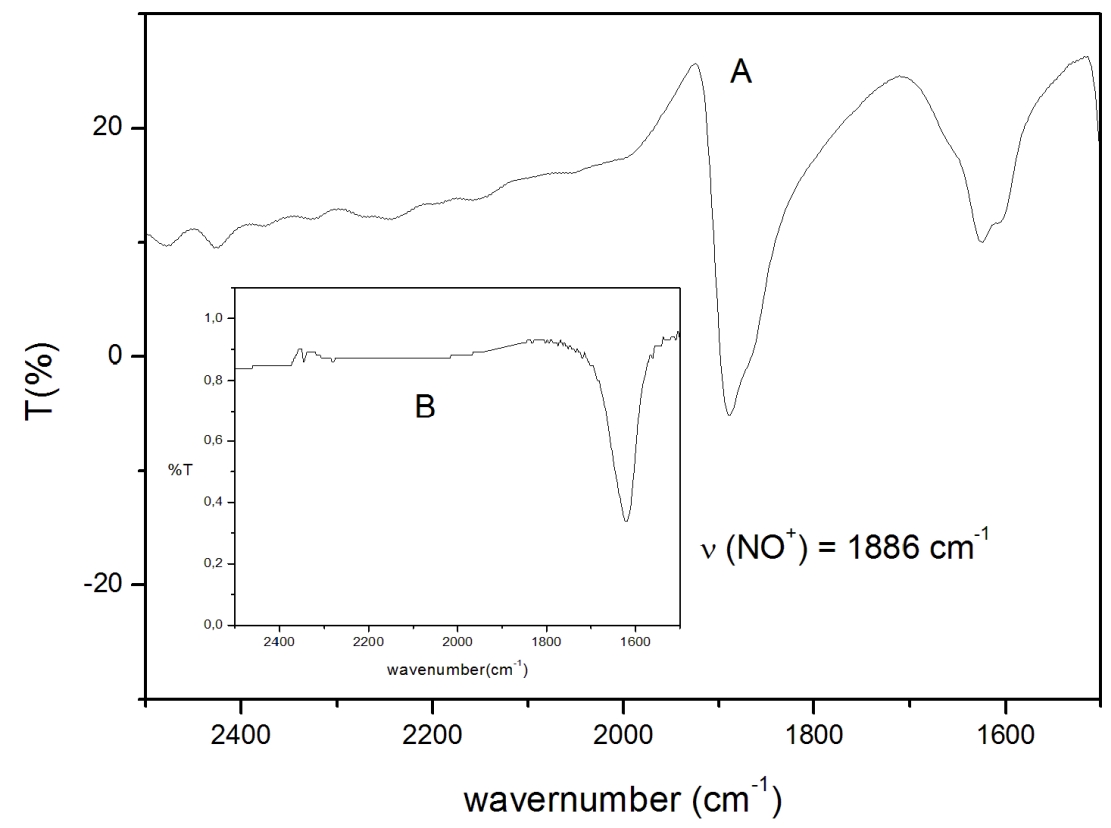

Figure 6. Changes in the vibrational spectrum of cis-[Ru(NO)(df)(cyclen)]Cl $\mathrm{l}_{2}$ in $\mathrm{KBr}$ pellets after reduction with $\mathrm{Zn}(\mathrm{Hg})$.

For both complexes, the ratio between the transmittance of the peak associated with the $\mathrm{C}=\mathrm{O}$ stretching in $\mathrm{df}$ and the signal assigned to the stretching of the $\mathrm{N} \equiv \mathrm{O}$ is strongly increased. This is consistent with the results obtained in DPV.

\section{Conclusion}

In summary, based on the data obtained, one can infer that the complexes $\mathrm{Na}_{2}\left[\mathrm{Ru}(\mathrm{NO}) \mathrm{Cl}_{3}(\mathrm{df})\right]$ and cis$[\mathrm{Ru}(\mathrm{NO})(\mathrm{df})($ cyclen $)] \mathrm{Cl}_{2}$ have been synthesized. The data of the vibrational and electronic spectra showed that the df ligand is coordinated to the metal center in the both complexes and that there are the presence of the fragment $\{\mathrm{RuNO}\}^{6}$. From the differential pulse voltammetry data, it was verified that the complex feature redox processes involving the df and $\mathrm{NO}^{+}$, and this was noticed a sign in the cathodic waves assigned to a reduction in $\mathrm{NO}^{+}$coordinated. After chemical and electrochemical stimulus, it was found that this signal had current diminished, can be assigned to release of NO after reduction of the fragment $\{\mathrm{RuNO}\}^{6}$. With that, this paper proposes that the complexes synthesized and characterized here can be used as nitric oxide donor and these data encourage future studies that focus on the release of NO and the biological activity of these complex. 


\section{Acknowledgements}

The authors thank Brazilian agencies CNPq (No. 471182/2008-7 and 577470/2008-6). and CAPES for financial support.

\section{References}

[1] L. J. Ignarro, Academic Press, Los Angeles, 2000.

[2] M. J. Rose, P. K. Mascharak, Coord. Chem. Rev. 252 (2008) 2093-2114.

[3] D. A. Wink, J. B. Mitchell, Free Radical Biology and Medicine. 25 (1998) 434-456.

[4] P. L. Feldman, O. W. Griffith, C\&N. 20 (1993) 26-33.

[5] R. M. Clancy, S. B. Abramson, Proc Soc Exp Biol Med. 210, 2 (1995) 93-101.

[6] E. Tfouni, D. R. Truzzi, A. Tavares, A. J. Gomes, L. E. Figueiredo, D. W. Franco, Nitric Oxide 26 (2012) 38-53.

[7] F. G. Marcondes, A. A. Ferro, A. Souza-torsoni, M. Sumitani, M. J. Clarck, D. W. Franco, E. Franco, M. H. Krieger, Life Sciences 70 (2002) 2735-2752.

[8] G. B. Ritcher-Addo, P. Legzdins, Oxford University Press, 1992.

[9] K. Q. Ferreira, F. G. Santos, Z. N. Rocha, T. Guaratini, R. S. Silva, E. Tfouni, Inorg. Chem. Comm. 7 (2004) 204-208.

[10] E. Tfouni, K. Q. Ferreira, F. G. Doro, R. S. Silva, Z. N. Rocha, Coord. Chem. Rev. 249 (2005) 405-418.

[11] F. S. Oliveira, V. Togniolo, T. Pupo, A. C. Tedesco; R. S. Silva, Inorg. Chem. Comm. 7 (2004) 160-164.

[12] F. G. Doro, K. Q. Ferreira, Z. N. da Rocha, G. F. Caramori, A. J. Gomes, E. Tfouni. Coord. Chem. Rev. 306 (2016) 652-677.

[13] D. Bonaventura, C. N. Lunardi, G. J. Rodrigues, M. A. Neto, J. A. Vercesi, R. G. De Lima, R. S. Da Silva, L. M. Bendhack, J. Inorg. Biochem. 103 (2009) 1366-1374.

[14] R. G. Lima, M. G. Sauaia, D. Bonaventura, A. C. Tedesco, L. M. Bendhack. R. S. Da Silva, Inorg. Chim. Acta 359 (2006) 2543-2549.

[15] C. S. Freitas, A. C. Roveda, Jr., D. R. Truzzi, A. C. Garcia, T. M. Cunha, F. Q. Cunha, D. W. Franco, J. Med. Chem. 11, 58 (2015) 4439-4448.

[16] C. L. Kummer, T. C. Coelho, Rev. Bras. Anestesiol. 52 (2002) 498-512.

[17] F. Sayin, S. Kir, J. Pharm. Biomed. Anal. 25, 1 (2001) 153163.

[18] S. Fountoulaki, F. Perdih, I. Turel, D. P. Kessissoglou, G. Psomas, J. Inorg. Biochem. 105, 12 (2011) 1645-1655.

[19] P. C. Andrews, R. L. Ferrero, P. C. Junk, I. Humar, Q. Luu, K. Nguyen, J. W. Taylor, J. Chem. Soc., Dalton Trans. 39 (2010) 2861-2868.

[20] A. Tarushi, C. Kakoulidou, C. P. Raptopoulou, V. Psycharis, D. P. Kessissoglou, I. Zoi, A. N. Papapoulos, G. Psomas, J.
Inorg. Biochem. 170 (2017) 85-97.

[21] F. G. Doro, E. E. Castellano, L. A. B. Moraes, M. N. Eberlin, E. Tfouni, Inorg. Chem. 47, 10 (2008) 4118-4125.

[22] V. A. Emel'yanov, I. A. Baidina, S. A. Gromilov, J. Sctruc. Chem. 53, 2 (2012) 341-346.

[23] K. Q. Ferreira, L. N. Cardoso, S. Nikolaou, Z. N. Rocha, R. S. Silva, E. Tfouni, Inorg. Chem. 44 (2005) 5544-5546.

[24] K. Q. Ferreira, A. M. Lucchesi, Z. N. Rocha, R. S. Silva, Inorg. Chim. Acta. 328 (2002) 147-151.

[25] C. M. Che, C. K. Poon, Pure and Applied Chemistry 60 (1998) 495-500.

[26] D. D. Walker, H. Taube, Inorg. Chem. 20 (1981) 2828-2834.

[27] F. D. Oliveira, K. Q. Ferreira, D. Bonaventura, L. M. Bendhack, A. C. Tedesco, S. D. Machado, E. Tfouni, R. S. Silva, J. Inorg. Biochem. 101, 320 (2007) 313-320.

[28] I. P. Evans, A. Spenar, G. J. Wilkinson, J. Chem. Soc., Dalton Trans. (1973) 204.

[29] E. Tfouni, D. W. Franco, B. R. McGarvey, M. Krieger, Coord. Chem. Rev. 236, (2003) 57-69.

[30] L. A. Berben, M. C. Faia, N. R. M. Crawford, J. R. Long, Inorg. Chem. 45 (2006) 6378-6386.

[31] F. Roncaroli, M. E. Ruggiero, D. W. Franco, G. L. Estiu, J. A. Olabe, Inorg. Chem. 41 (2002) 5760-5769.

[32] G. Bandoli, A. Dolmella, T. I. A. Gerber, J. G. H. Du Preez, Inorg. Chim. Acta 294 (1999) 114-118.

[33] A. Trinchero, S. Bonora, A. Tinti, G. Fini, Biopolymers, 74 (2004) 120-124.

[34] G. B. Deacon, R. J. Phillips. Coord. Chem. Rev. 33 (1980) 227-250.

[35] J. H. Enemark, R. D. Felthmam, Coord. Chem. Rev. 13 (1974) $339-406$.

[36] P. C. Ford, I. M. Lorkovic, Chem. Rev. 102 (2002) 993-1017.

[37] C. G. Pierpont, R. M. Buchanan, Coord. Chem. Rev. 38 (1981) 45-87.

[38] D. Nematollahi, A. Amani, Chem. Pharm. Bull. 56 (2008) 513-517.

[39] R. A. Metcalfe, A. B. P. Lever, Inorg. Chem. 36 (1997) 47624771.

[40] V. Poelhsitz, D. Sc. Thesis, Centro de Ciências Exatas e de Tecnologia, UFSCar, 2005.

[41] J. C. Toledo, L. G. F. Lopes, A. A. Alves, L. P. Silva, D. W. Franco, J. Inorg. Biochem. 89 (2002) 267-271.

[42] P. G. Zanichelli, H. F. G. Estrela, R. C. Spadari-Bratfisch, D. M. Grassi-Kassisse, D. W. Franco, Nitric Oxide, 16 (2007) 189-196.

[43] F. O. N. Silva, S. X. B. Araújo, A. K. M. Holanda, E. Meyer, F. A. M. Sales, I. C. N. Diógenes, I. M. M. Carvalho, I. S. Moreira, L. G. F. Lopes, Eur. J. Inorg. Chem. 10 (2006) 20202026. 
[44] L. G. F. Lopes, A. Wieraszko, Y. El-Sherif, M. J. Clarke, Inorg. Chim. Acta, 312 (2001) 15-22.

[45] K. Q. Ferreira, E. Tfouni, J. Braz. Chem. Soc. 21 (2010) 13491358.
[46] R. S. Silva, S. I. Gorelsky, E. S. Dodsworth, E. Tfouni, A. B. P. Lever, Dalton Trans. 22 (2000) 4078-4088. 